\title{
Senyawa 5,3' 'Dihidroksi-7,4'-Dimetoksiflavon dari Kulit Batang Tanaman Akway (Drimys beccariana Gibs) dan Aktivitas Antimalarianya
}

\section{5,3'-Dihidroxy-7,4'-Dimetoxyflavon Compound from Stembark Akway (Drimys beccariana Gibs) Plant and its Antimalarial Activity}

\author{
Tarso Rudiana ${ }^{1,2}$, Tati Herlina ${ }^{3}$, Euis Julaeha ${ }^{3}$ \\ ${ }^{1}$ Program Studi Kimia, Fakultas Sains dan Farmasi Universitas Mathla'ul Anwar Banten \\ Jalan Raya Labuan KM 23, Cikaliung Saketi, Pandegalang Banten Indonesia, 42273 \\ ${ }^{2}$ Program Studi Kimia Fakultas Sains dan Teknologi UIN Syarif Hidayatullah Jakata \\ Jalan Ir. H. Juanda No. 95, Ciputat Tangerang Selatan Banten Indonesia, 15411 \\ ${ }^{3}$ Departemen Kimia Fakultas Matematika dan Ilmu Pengetahuan Alam Universitas Padjadjaran \\ Jalan Raya Sumedang Bandung KM 21, Jatinangor Sumedang Jawa Barat Indonesia, 45363 \\ Email:tarso.rudiana@unmabanten.ac.id,tarso.rudiana@uinjkt.ac.id
}

Received: April 2018; Revised: July 2018; Accepted: August 2018; Available Online: November 2018

\begin{abstract}
Abstrak
Akway (Drimys beccariana Gibs) merupakan tanaman endemik Papua. Secara Etnobotani digunakan sebagai tanaman obat, salah satunya digunakan sebagai obat malaria. Penelitian ini bertujuan untuk mengisolasi, menentukan struktur kimia serta mengevaluasi aktivitas antimalaria dari kulit batang $D$. beccariana. Serbuk halus kulit batang $D$. beccariana dimaserasi dengan metanol dan difraksionasi dengan menggunakan $n$-heksana dan etil asetat. Ekstrak etil asetat direfraksinasi menggunakan kromatografi cair vakum (KCV) secara gradien $(n-$ heksana:etilasetat:metanol). Fraksi hasil KCV dipisahkan dengan kromatografi kolom gravitasi secara berulang dan kromatografi lapis tipis preparatif (KLT-P) untuk mendapatkan Isolat 1. Isolat 1 ditentukan strukturnya dengan metode spektroskopi yang meliputi UV-Vis, IR, NMR 1D, dan 2D. Isolat 1 ditentukan struktur senyawanya yaitu 5,3'-dihidroksi-7,4'-dimetoksiflavon. Senyawa 5,3'-dihidroksi-7,4'-dimetoksiflavon dievaluasi aktivitas antimalaria terhadap Plasmodium falciparum secara in vitro dengan aktivitas antimalaria lebih baik daripada artemisinin.
\end{abstract}

Kata kunci: Akway; Drimys beccariana Gibs; flavonoid; Malaria; Plasmodium falciparum.

\begin{abstract}
Akway (Drimys beccariana Gibs) is an endemic plant of Papua. Ethnobotany is used as a medicinal plant, one of which is used as a malaria drug. This study aims to isolate, determine the chemical structure and evaluate the antimalarial activity of D. beccariana stem bark. Powder of D. beccariana bark is macerated with methanol and fractionated using $\mathrm{n}$-hexane and ethyl acetate. Ethyl acetate extract was fractionated using gradient liquid chromatography (KCV) (n-hexane: ethyl acetate: methanol). The KCV fraction was separated by repeated gravity column chromatography and preparative thin layer chromatography (TLC-P) to obtain Isolate $\mathbf{1}$. Isolate $\mathbf{1}$ was determined by spectroscopic methods including UV-Vis, IR, 1D NMR, and 2D. Isolate $\mathbf{1}$ is determined by its compound structure which is 5,3'-dihydroxy-7,4'-dimethoxyflavone. 5,3'-dihydroxy-7,4'-dimethoxyflavone compounds evaluated antimalarial activity against Plasmodium falciparum in vitro with antimalarial activity better than artemisinin.
\end{abstract}

Keywords: Akway; Drimys beccariana Gibs; flavonoid; malaria; Plasmodium falciparum.

DOI: http://10.15408/jkv.v4i2.7775 


\section{PENDAHULUAN}

Flavonoid merupakan kelompok senyawa fenol yang memiliki beragam aktivitas, salah satu aktivitas yang dimiliki oleh golongan senyawa metabolit sekunder ini adalah sebagai antimalaria (Widyawaruyanti et al., 2011). Senyawa flavonoid dari Artemisia аппиа yaitu luteolin, kuersetin, dan apigenin mempunyai aktivitas antimalaria dengan nilai $\mathrm{IC}_{50}$ sebesar 3.14; 4.53 dan 5.40 ppm (Ferreira et al., 2010). Perbedaan nilai $\mathrm{IC}_{50}$ pada aktivitas antimalaria selain dipengaruhi oleh jenis metabolit sekunder, juga dipengaruhi oleh substituen. Menurut Kaur et al. (2009) senyawa aktif antimalaria golongan flavonoid sangat dipengaruhi oleh substituen prenil, hidrogen, halogen, hidroksil, alkil, alkoksi, metoksi, amino atau asilamino.

Menurut WHO, setiap tahunnya sekitar 300-500 juta orang terinfeksi malaria dan 2.7 juta diantaranya meninggal dunia, dengan angka kesakitan tertinggi di 90 negara (WHO, 2010). Menurut riset kesehatan dasar, insiden malaria penduduk Indonesia tahun 2007 adalah 2.9\% dan tahun 2013 adalah 1.9\%. Meskipun insiden malaria di Indonesia sejak tahun 2007 cenderung menurun, tetapi insiden dan prevalensi tertinggi masih terjadi di lima provinsi yaitu di provinsi Papua, Nusa Tenggara Timur, Papua Barat, Sulawesi Tengah, dan Maluku (Riskesdas, 2013). Papua merupakan salah satu daerah endemik malaria, masyarakat setempat selain menggunakan obat-obatan sintesis, juga menggunakan tanaman sebagai pengobatan tradisional. Salah satu tanaman endemik Papua yang biasa digunakan sebagai pengobatan malaria adalah tanaman akway (Drymis beccariana Gibs). Masyarakat setempat menggunakan kulit kayu dan daun $D$. beccariana dengan cara dirajang dan diseduh air panas kemudian diminum (Parubak, 2013).

Beberapa senyawa telah berhasil diisolasi dan ditentukan struktur kimianya dari tanaman $D$. beccariana diantaranya senyawa golongan triterpoenoid yaitu $3-\alpha-$ hidroksikukurbita-5(6)-ena-2,3-on (Simbolon, 2010). Lima senyawa golongan flavonoid, diantaranya 5,7-dihidroksi-4' -metoksiflavon; 5,4'-dihidroksi-7,3' 'dimetoksiflavon; 5,4' dihidroksi-7-metoksi-3-pentilflavon; 5hidroksi-7,4'-dimetoksi-3' - pentilflavon dan 5,4'-dihidroksi-7-metoksi-3'-3,7-dimetil-2oktanonflavon (Mailoa, 2011; Noviyanto, 2013: Wati, 2013).
Penelitian terhadap kulit batang $D$. beccariana dan aktivitasnya terhadap antimalaria belum penah dilaporkan. Penelitian ini bertujuan menentukan senyawa flavonoid pada kulit batang tumbuhan $D$. beccariana dan aktivitasnya terhadap $P$. falciparum.

\section{METODE PENELITIAN Bahan dan Alat Penelitian}

Kulit batang $D$. beccariana diperoleh dari Provinsi Papua Barat Indonesia, berbagai pelarut organik untuk pemisahan ( $n$-heksana, etil asetat, aseton, metanol) grade teknis redistilasi, kloroform (p.a, Merck), silika $\mathrm{GF}_{254}$ (Merck), silika G60 (Merck), pelat kromatografi lapis tipis silika $\mathrm{GF}_{254}$ (Merck, $0.25 \mathrm{~mm}$ ), pereaksi semprot $\mathrm{AlCl}_{3} 5 \%$ dalam etanol. $P$. falciparum galur 3D7 (sensitif klorokuin), media kultur RPMI-1640 (Sigma Aldric), HEPES (Sigma Aldric), natrium bikarbonat, akuabides (Sigma Aldric), DMSO (Merck), artemisinin, serum $\mathrm{AB}$, dan pewarna Giemsa.

Rotary evaporator (Buchi), spektrofotometer UV-Vis Shimazu UV-160A. Spektrofotometer IR Parking Elmer 1760XFTIR. Spektrometri massa HR-ESI-TOFMS. Spektrometer ${ }^{1} \mathrm{H}-\mathrm{NMR} 500 \mathrm{MHz}$ dan ${ }^{13} \mathrm{C} 125$ $\mathrm{MHz}$ JEOL ECA 500. Kromatografi vakum cair, kromatografi kolom, lampu UV Vilbert Luomart ( $\lambda 254 \mathrm{~nm}$ and $\lambda 365 \mathrm{~nm}$ ), plate 96 wel, dan inkubator.

\section{Ekstraksi dan Isolasi}

Serbuk kering kulit batang $D$. beccariana $(2.0 \mathrm{~kg})$ diekstraksi dengan menggunakan pelarut metanol selama 3x24 jam pada suhu kamar. Ekstrak metanol yang diperoleh kemudian disaring dan diuapkan pelarutnya dengan menggunakan vacuum rotary evaporator pada suhu $40{ }^{\circ} \mathrm{C}$, sehingga diperoleh ekstrak metanol pekat (120.4 g). Ekstrak metanol pekat yang diperoleh kemudian dipartisi dengan metode ekstraksi cair-cair dalam corong pisah, menggunakan pelarut $n$-heksana, etil asetat, dan metanol dan dipekatkan dengan vakum evaporator. Selanjutnya ekstrak etil asetat pekat $(30.0 \mathrm{~g})$ dipisahkan dengan menggunakan metode kromatografi cair vakum (KCV) dengan fasa diam silika G60 dan fasa gerak menggunakan pelarut $n$-heksana, etil asetat, dan metanol yang dielusi secara gradien (v/v). Diperoleh lima fraksi (fraksi 1-5) hasil pemisahan dengan KCV. Fraksi 1 (4.2 g) dipisahkan dan 
dimurnikan dengan kromatografi kolom gravitasi, silika gel G60 (70-230 mesh) sebagai fasa diam dan $n$-heksana:etil asetat (7:3) sebagai fasa geraknya. Hasil pemisahan dari fraksi 1 diperoleh 10 fraksi (A-J).

Fraksi $\mathrm{H}$ sebanyak $1.5 \mathrm{~g}$ dipisahkan dengan kromatografi kolom gravitasi dengan fasa diam silika gel G60 (70-230 mesh) dan fasa gerak $n$-heksana:etil asetat (7:3), menghasilkan 7 fraksi gabungan (H.1-H.7). Fraksi H.3 (25 mg) menunjukkan adanya kandungan flavonoid, sehingga dipisahkan dan dimurnikan dengan menggunakan kromatografi lapis tipis preparatif (KLT-P) dengan fasa diam plat silika gel $\mathrm{GF}_{254}$ dan dielusi menggunakan pelarut $n$ heksana:kloroform (1:9) untuk mendapatkan Isolat $1(11 \mathrm{mg})$. Isolat 1 berbentuk padatan berwarna kuning dan larut sempurna dalam metanol, kemudian diuji kemurniannya dengan analisis KLT dua dimensi menggunakan berbagai pelarut organik.

\section{Penentuan Struktur Isolat}

Struktur kimia Isolat 1 ditentukan dengan menggunakan metode spektroskopi yang meliputi UV-Vis, IR, MS, dan NMR serta perbandingan data spektra yang diperoleh dengan literatur.

\section{Uji Aktivitas Antimalaria}

Uji aktivitas antimalaria dilakukan dengan menggunakan metode Desjardins (1979). P. falciparum galur 3D7 dikultur dalam Medium RPMI 1640 yang mengandung sel darah merah dengan hematokrit 5\%, dapar HEPES, serum $\mathrm{AB}$, dan $\mathrm{NaHCO}_{3}$ sesuai teknik Trager dan Jensen (1976). Uji aktivitas antimalaria ditentukan dengan parasitemia. Kultur $P$. falciparum ditempatkan ke dalam lempeng sumur 24 masing-masing berisi $1 \mathrm{~mL}$ kultur dengan parasitemia $\pm 1 \%$ dalam medium RPHS. Medium RPHS diganti dengan medium RPHS yang mengandung sampel uji berbagai konsentrasi. Kultur diinkubasi selama 48 jam, setelah inkubasi parasit dipanen dan dibuat sediaan apusan darah tipis yang diberi pewarnaan Giemsa. Selanjutnya dihitung persen parasitemia $P$. falciparum dengan menghitung jumlah eritrosit yang terinfeksi terhadap 500 eritrosit. Perhitungan parasitemia dan penghambatan pertumbuhan parasit dengan menghitung jumlah eritrosit yang terinfeksi setiap 500 eritrosit di bawah mikroskop. Persentase penghambatan tiap konsensentrasi digabungkan dan dianalisis menggunakan analisa probit dengan program SPSS untuk menentukan $\mathrm{IC}_{50}$. Hasil perhitungan dalam bentuk konsentrasi $\mu \mathrm{g} / \mathrm{mL}$ (ppm).

\section{HASIL DAN PEMBAHASAN}

Rumus molekul Isolat $\mathbf{1}$ ditetapkan sebagai $\mathrm{C}_{17} \mathrm{H}_{14} \mathrm{O}_{6}$ berdasarkan data spektrum $\begin{array}{llll}\text { HR-TOFMS } \quad[\mathrm{M}-\mathrm{H}]^{-} \quad(\mathrm{m} / \mathrm{z} & 313.2321)\end{array}$ perhitungan untuk massa rumus Isolat $\mathbf{1}$ adalah 314.2895. Bersama dengan data NMR (Tabel 1) dengan demikian diperoleh sebelas derajat ketidakjenuhan yang berasal dari tujuh $\mathrm{C}=\mathrm{C}$ $s p^{2}$, satu $\mathrm{C}=\mathrm{O}$, dan tiga dari siklik cincin flavon. Rumus struktur Isolat 1 dapat dilihat pada Gambar 1.<smiles>COc1cc(O)c2c(=O)cc(-c3ccc(OC)c(O)c3)oc2c1</smiles>

Gambar 1. Struktur kimia Isolat 1

Kromatogram lapis tipis senyawa $\mathbf{1}$ berpendar di bawah sinar UV pada $\lambda 254$ dan $365 \mathrm{~nm}$, menunjukkan adanya ikatan rangkap terkonjugasi. Spektrum UV-Vis Isolat 1 dalam metanol memberikan serapan maksimum pada $\lambda_{\text {maks }} 345.0 \mathrm{~nm}(\log \varepsilon 3.80)$ dan $268.5 \mathrm{~nm}(\log \varepsilon$ 3.81) yang menunjukkan serapan khas flavon (Markham, 1988). Berdasarkan pengukuran UV-Vis didapatkan dua puncak serapan. Puncak 1 menunjukkan serapan yang berhubungan dengan resonansi gugus sinamoil yang melibatkan cincin A pada panjang gelombang 310-350nm. Puncak 2 menunjukkan serapan yang berhubungan dengan resonansi gugus benzoil yang melibatkan cincin B dari flavon pada panjang gelombang 250-280 nm (Markham, 1988). Puncak serapan Isolat 1 mengalami pergeseran batokromik $\left(\lambda_{\text {maks }} 397.5 \mathrm{~nm}\right)$, pergeseran $\lambda_{\text {maks }}$ $52.5 \mathrm{~nm}$ pada pita 1 tanpa disertai penurunan intensitas akibat penambahan pereaksi penggeser $\mathrm{AlCl}_{3}$. Penambahan pergeseran 35 sampai $55 \mathrm{~nm}$ pada pita 1 menunjukkan adanya gugus $\mathrm{OH}$ pada C-5 kerangka flavon (Markham, 1988). Untuk menentukan gugus 
fungsional Isolat $\mathbf{1}$, terhadap Isolat $\mathbf{1}$ dianalisi FTIR. Berdasarkan spektrum IR Isolat $\mathbf{1}$ terlihat adanya gugus $\mathrm{O}-\mathrm{H}\left(3468.0 \mathrm{~cm}^{-1}\right), \mathrm{C}-\mathrm{H}$ alifatik $\left(2927.9 \mathrm{~cm}^{-1}\right), \mathrm{C}=\mathrm{C}$ aromatik $(1658,8$ $\left.\mathrm{cm}^{-1}\right), \mathrm{C}=\mathrm{O}\left(1598.9 \mathrm{~cm}^{-1}\right), \mathrm{C}-\mathrm{O}\left(1033.9 \mathrm{~cm}^{-1}\right)$, dan benzena disubstitusi $\left(829.4 \mathrm{~cm}^{-1}\right)$.

Analisis spektroskopi ${ }^{13} \mathrm{C}-\mathrm{NMR}$ digunakan untuk mengetahui jumlah dan jenis karbon-karbon yang terdapat pada Isolat $\mathbf{1}$. Spektrum ${ }^{13} \mathrm{C}$-NMR $\left(\mathrm{CD}_{3} \mathrm{OD}, 125 \mathrm{MHz}\right)$ Isolat 1 menunjukkan adanya 17 sinyal karbon, yang terdiri dari dua karbon $s p^{3}$ teroksigenasi $\delta_{C}$ 56.6 dan 56.7 ppm, empat belas karbon $s p^{2}$ terkonjugasi aromatik $\delta_{\mathrm{C}} 93.6 ; 99.3 ; 103.0$; $104.0 ; 110.6 ; 117.2 ; 122.2 ; 122.3 ; 150.0$; $150.0 ; 158.0 ; 162.0 ; 166.8$ dan 167.4 ppm dan satu karbon karbonil $\delta_{\mathrm{C}} 184.0 \mathrm{ppm}$.

Untuk mengetahui informasi pemecahan sinyal dari setiap karbon, maka dilakukan pengukuran ${ }^{13} \mathrm{C}-\mathrm{NMR}$ dengan teknik DEPT $135^{\circ}$, sehingga akan didapatkan informasi sinyal yang berasal dari karbon kuartener (-C-), metin (-CH-), metilen $\left(\mathrm{CH}_{2}-\right)$, dan metil $\left(\mathrm{CH}_{3}-\right)$. Sinyal pada $\delta_{\mathrm{C}} 56.6$ dan 56.7 ppm mengidikasikan adanya metil teroksigenasi. Sinyal pada pergeseran kimia $\delta_{\mathrm{C}}$ 93.6 dan 99.3 ppm merupakan khas karbon pada cincin A flavonoid. Isolat 1 memiliki sembilan karbon kuartener yang ditunjukkan dengan delapan sinyal yang tidak muncul pada spektrum karbon DEPT $135^{\circ}$. Enam karbon kuartener teroksigenasi $(=\mathrm{C}-\mathrm{O})$ yang muncul pada $\delta_{\mathrm{C}} 147.0 ; 150.0 ; 158.0 ; 162.0 ; 166.8$ dan 167.4 ppm, dua karbon kuartener tak teroksigenasi $(=\mathrm{C}-\mathrm{C})$ yang muncul pada $\delta_{\mathrm{C}}$ kurang dari $150.0 \mathrm{ppm}$ yaitu 103.0 dan 122.3 ppm serta satu karbon karbonil yang muncul pada $\delta_{\mathrm{C}} 184.0 \mathrm{ppm}$.

Spektrum ${ }^{1} \mathrm{H}-\mathrm{NMR} \quad\left(\mathrm{CD}_{3} \mathrm{OD}, \quad 500\right.$ $\mathrm{MHz}$ ) menunjukkan adanya sembilan sinyal dengan total duabelas proton, yang terdiri dari enam sinyal metin $s p^{2}$ yaitu, pada $\delta_{\mathrm{H}}(\mathrm{ppm})$ $7.53(1 \mathrm{H}, d d, \quad J=2.6 ; 8.4 \mathrm{~Hz}) ; 7.50(1 \mathrm{H}, d$, $J=1.9 \mathrm{~Hz}) ; 6.92(1 \mathrm{H}, d, J=8.4 \mathrm{~Hz}) ; 6.69(1 \mathrm{H}$, $d, J=1.9 \mathrm{~Hz}) ; 6.67(1 \mathrm{H}, s) ; 6.35(1 \mathrm{H}, d, J=2.6$ $\mathrm{Hz}$ ). Dua sinyal proton $s p^{3}$ teroksigenasi pada $\delta_{\mathrm{H}} 3.96(3 \mathrm{H}, s) ; 3.91(3 \mathrm{H}, s)$ dan satu sinyal hidroksi $\delta_{\mathrm{H}} 8.55(1 \mathrm{H}, s)$. Karakteristik proton ABX diamati pada pergeseran $\delta_{\mathrm{H}} 6.35 ; 6.92$ dan 7.53 ppm spesifik untuk H-2', H-5', dan H6' yang khas pada proton ABX cincin B flavonoid. Resonansi meta coupling diamati pada pergeseran $\delta_{\mathrm{H}} 7.50$ dan $6.69 \mathrm{ppm}$ spesifik untuk H-6 dan H-8 pada cincin A flavonoid.

Tabel 1. Data ${ }^{1} \mathrm{H}$ dan ${ }^{13} \mathrm{C}-\mathrm{NMR}$ Isolat 1 dan senyawa 5,3'-dihidroksi-7,4'-dimetoksiflavon (Devkota et al., 2012).

\begin{tabular}{|c|c|c|c|c|}
\hline No & $\begin{array}{c}\text { Senyawa } 1^{\mathrm{a}} \\
\delta_{\mathrm{H}}(\text { int.; mult.; } \Sigma \mathrm{H} ; J=\mathrm{Hz})\end{array}$ & $\begin{array}{c}\boldsymbol{\delta}_{\mathbf{C}} \\
(\mathbf{p p m})\end{array}$ & $\begin{array}{c}\text { Senyawa Pembanding } \\
\left.\delta_{\mathrm{H}} \text { (int.; mult.; } \Sigma \mathrm{H} ; \boldsymbol{J}=\mathbf{H z}\right)\end{array}$ & $\begin{array}{c}\boldsymbol{\delta}_{\mathbf{C}} \\
(\mathbf{p p m})\end{array}$ \\
\hline 2 & - & 166.8 & - & 165.1 \\
\hline 3 & $6.67(1 \mathrm{H} ; s)$ & 104.0 & $6.80(1 \mathrm{H} ; s)$ & 103.6 \\
\hline 4 & - & 184.0 & - & 181.8 \\
\hline 5 & - & 162.0 & - & 161.6 \\
\hline 6 & $7.50(1 \mathrm{H} ; d ; 1.9)$ & 99.3 & $6.37(1 \mathrm{H}, d, J=2.1)$ & 97.9 \\
\hline 7 & - & 167.4 & - & 163.8 \\
\hline 8 & $6.69(1 \mathrm{H} ; d ; 1.9)$ & 93.6 & $6.76(1 \mathrm{H} ; d, J=2.1)$ & 92.6 \\
\hline 9 & - & 158.0 & - & 157.2 \\
\hline 10 & - & 103.0 & - & 104.6 \\
\hline 1 ' & - & 122.3 & - & 122.8 \\
\hline 2 & $6.35(1 \mathrm{H} ; d ; 2.6)$ & 110.6 & $7.46(1 \mathrm{H} ; d, J=2.1)$ & 113.0 \\
\hline $3^{\prime}$ & - & 147.0 & - & 146.7 \\
\hline $4{ }^{\prime}$ & - & 150.0 & - & 151.2 \\
\hline 5, & $6.92(1 \mathrm{H} ; d ; 8.4)$ & 117.2 & $7.10(1 \mathrm{H} ; d ; J=8.5)$ & 112.0 \\
\hline $6{ }^{\prime}$ & $7.53(1 \mathrm{H} ; d d ; 2.6 ; 8.4)$ & 122.2 & $7.56(1 \mathrm{H} ; d d ; J=2.1 ; 8.5)$ & 118.9 \\
\hline $7-\mathrm{OCH}_{3}$ & $3.96(3 \mathrm{H} ; \mathrm{s})$ & 56.7 & $3.87\left(3 \mathrm{H} ; s ; \mathrm{O}-\mathrm{CH}_{3}\right)$ & 56.0 \\
\hline 4 '- $\mathrm{OCH}_{3}$ & $3.92(3 \mathrm{H} ; s)$ & 56.6 & $3.37\left(3 \mathrm{H} ; s ; \mathrm{O}-\mathrm{CH}_{3}\right)$ & 55.7 \\
\hline
\end{tabular}

\footnotetext{
a (JEOL tipe ECA, $500 \mathrm{MHz}$ dalam $\mathrm{CD}_{3} \mathrm{OD}$ ).

b (Bruker 300 Spektrometer, $500 \mathrm{MHz}$ dalam $\mathrm{CDCl}_{3}$ ).
} 
Korelasi ${ }^{1} \mathrm{H}-{ }^{1} \mathrm{H}-\mathrm{COSY}$ senyawa 1 pada Gambar 2 menunjukkan korelasi dua ikatan (2J) antara proton-proton H5'-H6'. Analisis dengan HMBC menunjukkan sejumlah puncak silang disebabkan penjodohan jarak jauh $\mathrm{H}, \mathrm{C}$ $\left({ }^{2} J_{C, H}\right.$ dan $\left.{ }^{3} J_{C, H}\right)$. Penentuan posisi proton metil teroksigenasi Isolat 1 yang beresonansi pada $\delta_{\mathrm{H}}$ 3.91 dan $3.96 \mathrm{ppm}$ dikonfirmasi melalui spektrum HMBC. Spektrum HMBC (Gambar 2) menunjukkan korelasi pada $\delta_{\mathrm{H}} 3.91 \mathrm{ppm}$ terhadap $\delta_{\mathrm{C}} 167.4 \mathrm{ppm}$ dan $\delta_{\mathrm{H}} 3.96 \mathrm{ppm}$ terhadap $\delta_{\mathrm{C}} 150.0 \mathrm{ppm}$ yang menyarankan bahwa adanya metil teroksigenasi terletak pada cincin A dan cincin B flavonoid.

Proton pada cincin A, yaitu pada $\mathrm{H}-8$ $\left(\delta_{\mathrm{H}} 6.69 \mathrm{ppm}\right)$ terjodoh ${ }^{2} J$ terhadap $\mathrm{C}-9\left(\delta_{\mathrm{C}}\right.$ $158.0 \mathrm{ppm})$. Proton pada cincin B (H-5') terjodoh pada 2 karbon tetangganya yaitu, ${ }^{2} J$ terhadap C-4' $\left(\delta_{\mathrm{C}} 150.0 \mathrm{ppm}\right)$ dan ${ }^{2} J$ terhadap C-6' $\left(\delta_{\mathrm{C}} 122.2 \mathrm{ppm}\right) . \mathrm{H}^{-6} 6^{\prime}$ dengan $\delta_{\mathrm{H}} 7.53 \mathrm{ppm}$ terjodoh ${ }^{3} J$ terhadap C-2 $\left(\delta_{\mathrm{C}} 166.8 \mathrm{ppm}\right)$. Pada cincin $\mathrm{C}$ proton $\mathrm{H}-3\left(\delta_{\mathrm{H}} 6.67 \mathrm{ppm}\right)$ terjodoh ${ }^{2} J$ terhadap C-2 ( $\left.\delta_{\mathrm{C}} 166.8 \mathrm{ppm}\right)$.

Berdasarkan spektrum UV diperoleh informasi bahwa Isolat $\mathbf{1}$ termasuk senyawa golongan flavon dengan gugus $-\mathrm{OH}$ terikat pada C-5. Kehadiran flavonoid diperkuat oleh adanya gugus $\mathrm{OH}, \mathrm{C}=\mathrm{C}$ aromatik, $\mathrm{C}=\mathrm{O}$, dan $\mathrm{C}-\mathrm{O}$, dari spektrum IR. Berdasarkan spektra HR-TOFMS, ${ }^{1} \mathrm{H}-\mathrm{NMR},{ }^{13} \mathrm{C}-\mathrm{NMR}$, DEPT $135^{\circ}$ dan 2D-NMR diprediksi bahwa Isolat 1 memiliki 17 atom karbon, 14 atom hidrogen, dan 6 atom oksigen dengan rumus molekul $\mathrm{C}_{17} \mathrm{H}_{14} \mathrm{O}_{6}$, dengan sebelas derajat ketidakjenuhan.

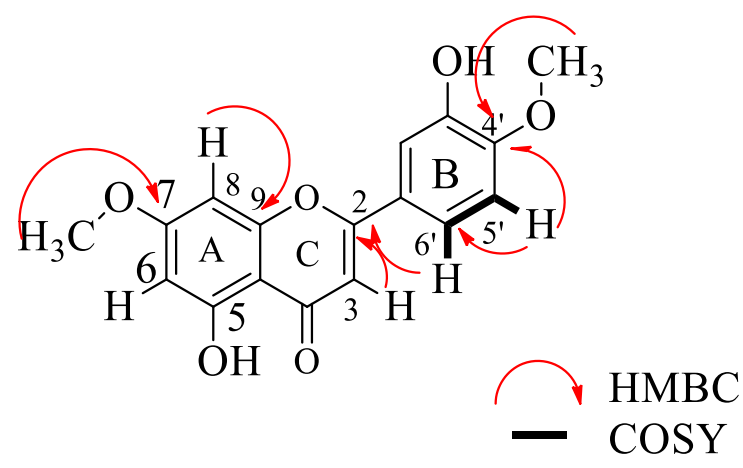

Gambar 2. Korelasi ${ }^{1} \mathrm{H}-{ }^{1} \mathrm{H}-\mathrm{COSY}$ dan HMBC Isolat 1

Perbandingan data NMR Isolat $\mathbf{1}$ dengan senyawa piloin yang diperoleh dari Diplomorpha ganpi (Devkota et al., 2012), menunjukkan bahwa kedua senyawa memiliki tingkat kesesuaian yang sangat tinggi, sehingga Isolat 1 diidentifikasi sebagai piloin (5,3'dihidroksi-7,4'-dimetoksiflavon). Senyawa ini pertama kalinya dilaporkan dari spesies $D$. beccariana. Data perbandingan nilai pergeseran kimia ${ }^{1} \mathrm{H}-\mathrm{NMR}$ dan ${ }^{13} \mathrm{C}-\mathrm{NMR}$ Isolat $\mathbf{1}$ dengan piloin (5,3'-dihidroksi-7,4'dimetoksiflavon) ditunjukkan pada Tabel 1 .

\section{Aktivitas Antimalaria}

Senyawa

dimetoksiflavon

5,3'-dihidroksi-7,4'hasil isolasi dievaluasi aktivitas antimalaria terhadap $P$. falciparum galur 3D7. Pada penelitian ini digunakan senyawa artemisinin sebagai kontrol positif. Berdasarkan hasil analsis, senyawa 5,3'dihidroksi-7,4'-dimetoksiflavon memberikan aktivitas antimalaria dengan nilai $\mathrm{IC}_{50}$ sebesar 0.51 ppm sedangkan artemisinin sebagai kontrol positif memberikan aktivitas dengan nilai $\mathrm{IC}_{50}$ sebesar $8,47 \mathrm{ppm}$. Berdasarkan Fidock et al. (2004) suatu senyawa dikategorikan senyawa aktif antimalaria apabila memberikan nilai inhibisi sebesar 1-5 ppm.

Mekanisme kerja penghambatan senyawa flavonoid terhadap $P$. falciparum, berbeda dengan mekanisme kerja dari golongan lain seperti alkaloid, terpenoid, dan golongan lainnya (Widyawaruyanti, 2011). Ada beberapa target lokasi kemoterapi pada pengobatan malaria diantaranya citosol, membran parasit, vakuola makanan, mitokondria, apikoplas, dan eksra seluler (Fidock et al., 2004). Mekanisme yang tepat dari golongan flavonoid belum diketahui dengan jelas (Kaur et al., 2009). Pada senyawa 5,3'-dihidroksi-7,4'-dimetoksiflavon memiliki gugus metoksi pada $\mathrm{C}-7$ cincin $\mathrm{A}$ dan gugus $\mathrm{OH}$ pada $\mathrm{C}-3^{\prime}$ cincin $\mathrm{B}$, diduga gugus $\mathrm{OH}$ pada C-3' dapat menurunkan aktivitas antimalaria. Menurut Rudrapal and Chetia (2017) flavonoid dengan gugus $\mathrm{OH}$ memiliki karakter asam dan dapat berperan dalam penghambatan parasit malaria pada vakuola makanan. Gugus $\mathrm{OH}$ dari senyawa golongan fenolik dapat diubah menjadi radika anion fenoksi yang stabil seperti semikuinon yang dapat memperbaiki stres oksidatif pada komponen seluler parasit protein atau DNA (Rudrapal and Chetia, 2017). Mekanisme penghambatan dari senyawa golongan flavonoid belum diketahui dengan pasti dan perlu dikaji lebih lanjut melalui mekanisme penghambatannya. 


\section{SIMPULAN}

Kulit batang D. beccariana mengandung flavonoid 5,3'-dihidroksi-7,4'dimetoksiflavon yang memiliki aktivitas antimalaria terhadap $P$. falciparum dengan nilai $\mathrm{IC}_{50}$ sebesar $0.51 \mathrm{ppm}$. Aktivitas senyawa 5,3'-dihidroksi-7,4'-dimetoksiflavon lebih aktif dibandingkan artemisinin.

\section{UCAPAN TERIMA KASIH}

Terima kasih kepada Kementerian Riset, Teknologi, dan Pendidikan Tinggi melalui Beasiswa Program Pendidikan Dalam Negeri tahun 2013. Prof. Dr. Unang Supratman atas bantuan dan bimbingannya, Dr. Sofa Fajriah dan Dr. Akhmad Darmawan di Pusat Penelitian LIPI Serpong yang telah membantu dalam analisis NMR. Uji Pratomo, M.Si di Laboratorium PPBS Unpad yang telah mengkonfirmasi spektroskopi massa dan Faisal Hermanto, M.Si., Apt. di Fakultas Farmasi Unjani yang telah membantu analisis aktivitas antimalaria.

\section{DAFTAR PUSTAKA}

Desjardins RE, Canfield CJ, Haynes JD, Chulay JD. 1979. Quantitative assessment of antimalarial activiy in vitro by a semiautomated microdilution technique. Antimicrob. Agents Chemother. 16(6): 710-718.

Devkota PH, Yoshizaki K, Yahara S. 2012. Piloin $5-O$ - $\beta$-D-Glucopyranoside from the stems of Diplomorpha ganpi. Biosc. Biotechnol. Biochem. 76(8): 1555-1557.

Ferreira J, Luthria D, Sasaki T, Heyerick A. 2010. Flavonoids from Artemisia annua L. as Antioxidants and Their Potential Synergism With Artemisinin against Malaria and Cancer. Molecule. 15: 31353170.

Fidock DA, Rosenthal PJ, Croft SL, Brun R, Nwaka S. 2004. Antimalarial Drug Discovery: Efficacy Models for Compound Screening. Nature. 3: 509-520.

Kaur K, Jain M, Kaur T, Jain R. 2009. Antimalarials from Nature. Bioorganic and
Medicinal Chemistry Journal. 19: 32293256.

Mailoa JA. 2011. Flavonoid dari Kulit Kayu Akway (Drymis beccarriana Gibs) yang Beraktivitas Antikanker Terhadap Sel Kanker Payudara T47D. [Skripsi]. Universitas Padjadjaran. Bandung.

Markham KR. 1988. Cara Mengidentifikasi Flavonoid. Bandung (ID): Penerbit ITB. 3953.

Noviyanto R. 2013. Flavonoid dari Ekstrak Etil Asetat Kulit Kayu Akway (Drymis beccariana Gibs). [Skripsi]. Universitas Padjadjaran. Bandung.

Parubak AS. 2013. Senyawa Flavonoid yang Bersifat Antibakteri dari Akway (Drimys beccariana Gibbs). Chemistry Progress. 6(1): 34-37.

Riskesdas. 2013. Riset Kesehatan Dasar Tahun 2013. Badan Penelitian dan Pengembangan Kesehatan. Kementrian Kesehatan Republik Indonesia.

Rudrapal M, Chetla D. 2017. Plant Flavonoids as Potential Source oh Future Antimalarial Leads. Sys Rev. Pharm. 8(1): 13-18.

Simbolon AP. 2010. Isolasi dan Karakterisasi Senyawa Aktif Antikanker dari Tumbuhan Akway (Drymis Beccariana Gibbs) dan Pengaruhnya Terhadap Sel Kanker Payudara T47D. [Skripsi]. Universitas Padjadjaran. Bandung.

Wati, I. 2013. Flavonoid dari ekstrak Kulit Batang Akway (Drymis Beccariana, Gibbs) dan aktivitasnya Terhadap Sel Kanker Leukimia P-388. [Tesis]. Universitas Padjadjaran. Bandung.

WHO. 2010. Roll back malaria. WHO Partnership, Economic Costs of Malaria, February 9, 2010, Geneva, Switzerland, pp: 35.

Widyawaruyanti A, Zaini NC, Syafruddin. 2011. Mekanisme dan Aktivitas Antimalaria dari Senyawa Flavonoid yang diisolasi dari Cempedak Arthocarpus campeden. Jurnal Biosains. 13(2): 67-77. 